\title{
CHINESE BUDDHIST SCULPTURE OF THE EARLY PERIOD. ICONOGRAPHIC FEATURES
}

Summary: The development period of the art of Buddhist sculpture from the mid and late era of Eastern Han to the era of Western Jin is addressed in this article. The Buddhist sculpture of this period is called early Chinese Buddhist sculpture.

During this period, before individual Buddhist sculptures became official objects of worship, Buddha images were made on stone carvings in tombs, on money trees, bronze mirrors, hunping vessels, etc. They have many similarities between each other, and therefore are significantly different from Buddhist sculptures of the later period. Based on currently available archaeological materials, relief was the main form of Buddhist sculptures of this period; sculptures mainly served as decor and were not an object of worship. In terms of purpose and meaning, they were mainly associated with funeral rituals, beliefs about happy omens, beliefs about celestials, early Taoist and other ideas, etc.

The early Chinese Buddhist sculpture dates from the late Eastern Han（东汉 中 晚期， 90-220), the Three Kingdoms（三国， 220-280) and Western Jin (西晋, 266-316). During this period, before individual Buddhist sculpture became an official object of worship, Buddha images were made on stone carvings in tombs (墓葬 石刻), money trees (摇钱树) ${ }^{1}$,

1. A money tree (摇钱树) is a funeral utensil that was used in the Sichuan, Chongqing, and in other regions during the Han and Wei eras. This item consisted of a base and a tree trunk with leaves. The base was ceramic, there were also bronze and stone ones: for the most part, they were in the shape of a mountain, tapering upwards, also found in the form of a ram, a lion, a head of an animal, etc. On the top of the base, there was a hole with a diameter of 1 to $5 \mathrm{~cm}$, in which a tree trunk was inserted. The trunk and leaves were cast from copper. The trunk was relatively high and consisted of 4 to 6 parts, each of which had 4 holes through which 1 or 2 leaves were hung. Figures of the phoenix, goddess Sivanmu, immortal saints, dragon, plants, coins, etc. were usually cast on the leaves. The technique used for casting Buddha figures on a money tree has the classical simplicity of the Han era, laconicism, and carving style, combining unity and detail.
After putting in order and combining material on the remains of early Buddhist sculptures, the following features of the art of sculpture can be distinguished:

1. In many ways, the early Buddhist sculptures expressed the early style of Gandhara. 2. The early Buddhist statues were closely related to the themes of the celestials and Huang Lao. 3. Buddhist sculpture did not occupy the most respected position. These sculptures mainly performed a decorative function, symbolized happiness and prosperity, and were not the main object of worship.

Two conclusions can be drawn from this: the art of early Buddhist sculptures and religion basically developed synchronously; after appearing in China, the art of Buddhist images immediately became Chinese.

Keywords: Buddhist sculpture of China of the early period, relief, decor, Gandhara style.

bronze mirrors (铜镜) ${ }^{2}$, hunping vessels (魂瓶) 3 , etc. In terms of purpose and semantic content, they were mainly associated with funeral rituals, beliefs about happy omens, beliefs about celestials, early Taoist and other ideas, etc.

2. A money tree (摇钱树) is a funeral utensil that was used in the Sichuan, Chongqing, and in other regions during the Han and Wei eras. This item consisted of a base and a tree trunk with leaves. The base was ceramic, there were also bronze and stone ones: for the most part, they were in the shape of a mountain, tapering upwards, also found in the form of a ram, a lion, a head of an animal, etc. On the top of the base, there was a hole with a diameter of 1 to $5 \mathrm{~cm}$, in which a tree trunk was inserted. The trunk and leaves were cast from copper. The trunk was relatively high and consisted of 4 to 6 parts, each of which had 4 holes through which 1 or 2 leaves were hung. Figures of the phoenix, goddess Sivanmu, immortal saints, dragon, plants, coins, etc. were usually cast on the leaves. The technique used for casting Buddha figures on a money tree has the classical simplicity of the Han era, laconicism, and carving style, combining unity and detail.

3. Bronze mirrors (铜镜) are mirrors cast in bronze. Such mirrors were household items in ancient China, as well as funerary utensils, often found in burials. Inscriptions and elegant patterns were usually cast on the reverse side of the mirrors. 


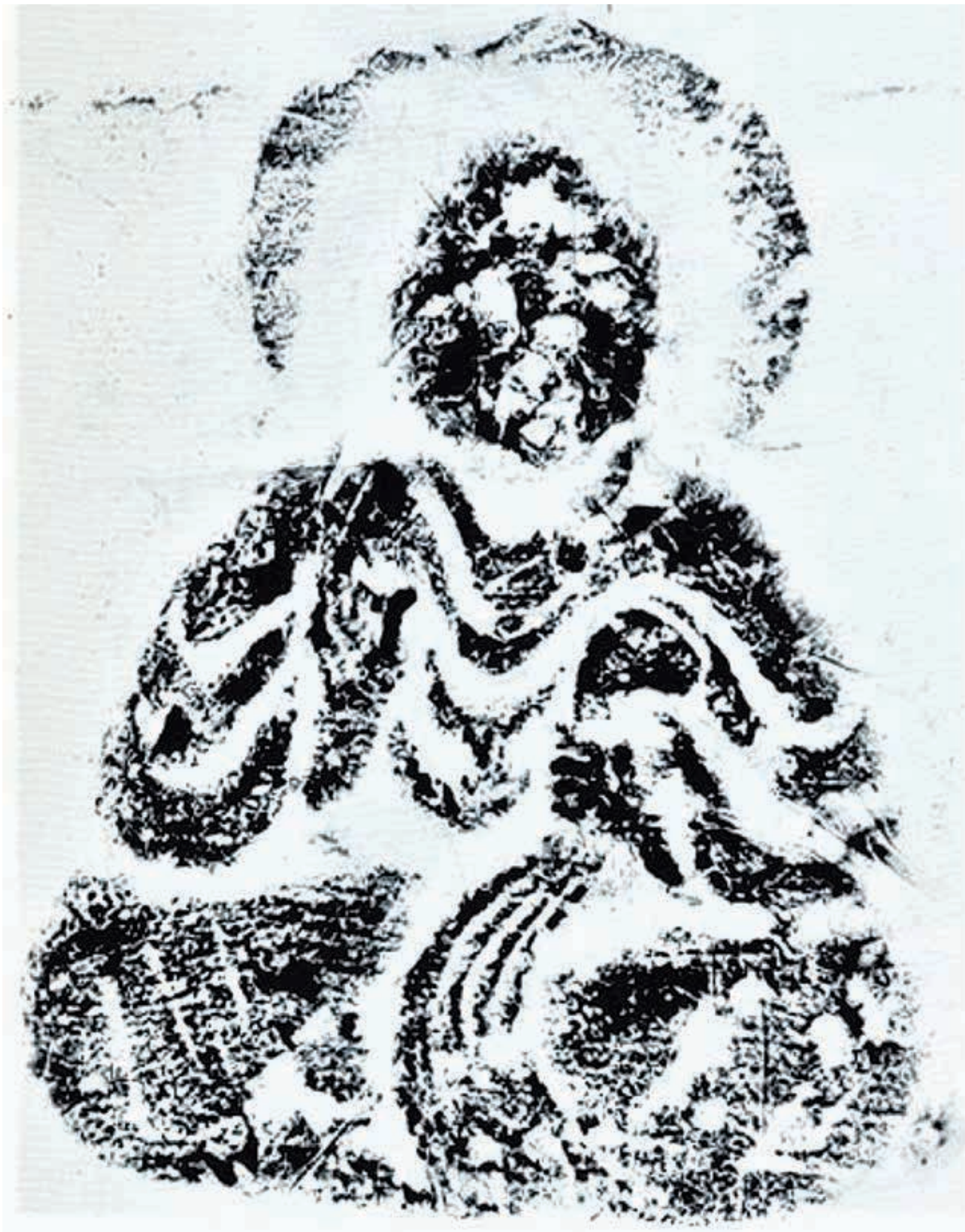

III. 1. A stone relief of a seated Buddha in a rock grave No. 1 - Leshan, Mahao. A rock. II century. Height $39.5 \mathrm{~cm}$, width $30 \mathrm{~cm}$. In the Mahao suburbs, the city of Leshan

During the period between the Middle and Late Dynasty of the Eastern Han (90-220) and until the Kingdom of Shu Han of the Three Kingdoms （三国 蜀汉 221-263)，early Buddhist sculptures were partially located in the southwestern region of China (西南 地区), in southern Shandong province, and in the northern part of Jiangsu province and the surrounding regions (鲁南 苏北 地区); they were located in the Middle and Lower Yangtze River (长江 中下游地区) during the period between the Kingdom of the Eastern Wu of the Three Kingdoms (三国 东吴 222-280) and Western Jin (西晋 266-316). 


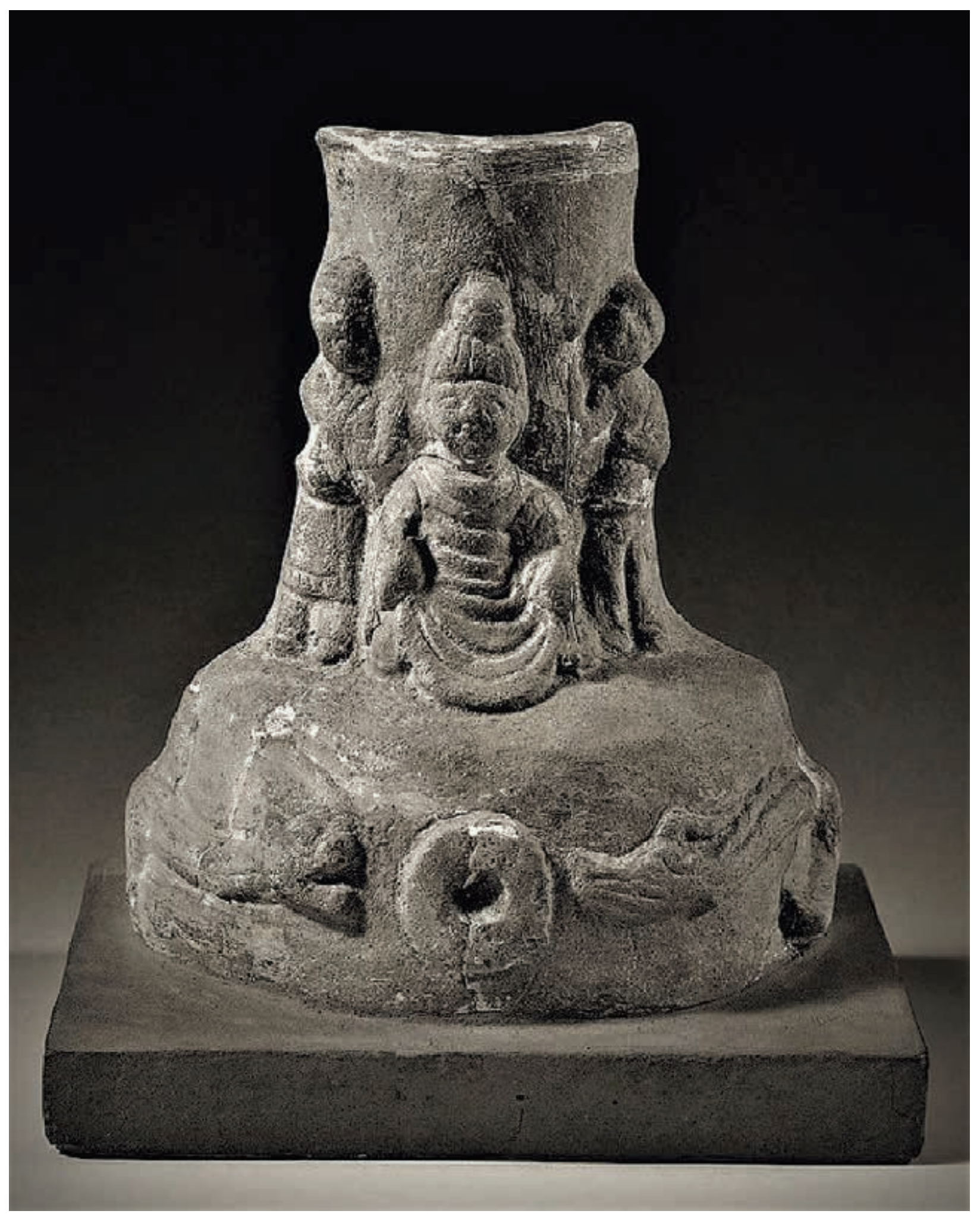

IIl. 2. The Buddha on a ceramic base of a money tree in Pengshan County. Ceramics. II-III centuries. Height $21 \mathrm{~cm}$. Nanjing Museum

The early Buddhist sculptures of the southwestern region (西南地区) mainly include the remains of sculptures from Sichuan (四川).

Based on actual archaeological materials, a stone relief of a sitting Buddha in the rock grave No. 1 in Leshan, Mahao（乐山麻浩一号 崖墓石刻 浮雕坐佛）

(Fig. 1), which was discovered in 1940 in the Mahao district of Leshan city on the door lintel of the rear burial chamber, is among stone-carved reliefs with the Buddha images on the door lintels of the rock graves. The height of the Buddha figure is $39.5 \mathrm{~cm}$, the width is $30 \mathrm{~cm}$. A high ushnisha (肉 䯽), a round halo were on the head of the Buddha; on the body, there was a kasaya with a U-shaped collar over the 


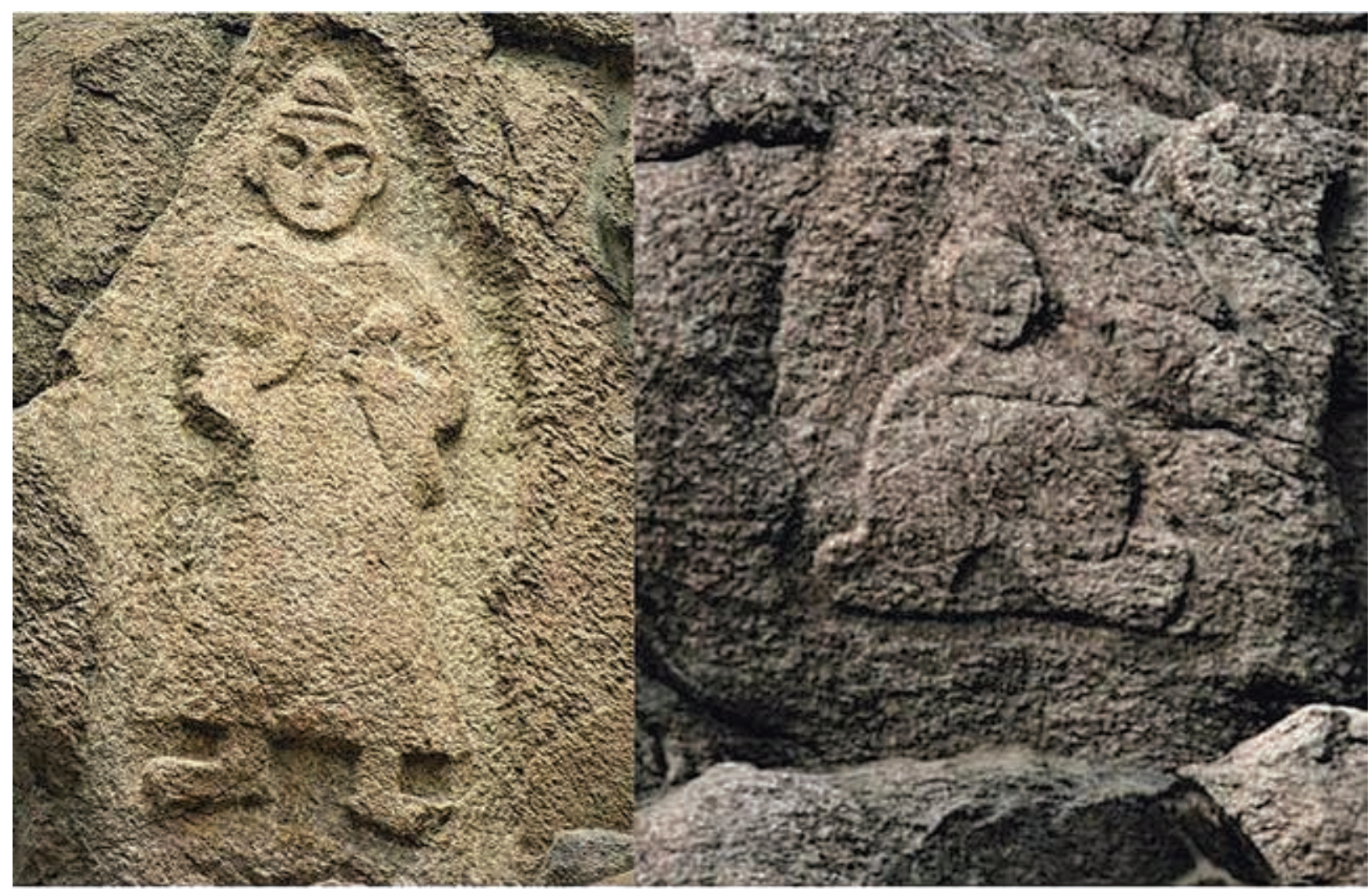

IIl. 3. Rock carvings on Kunwan Shan mountain. A rock. II-III centuries. About 105 relief figures of people of different sizes are carved on the surface of the mountain, the highest of which is $1.54 \mathrm{~m}$, and the lowest is $10 \mathrm{~cm}$. In the Haizhou District of Lianyungang City, Jiangsu Province

shoulder. On the right hand, the fingers are folded in the mudra of Abhai (施 无畏 印), the left is holding the belt. The Buddha is sitting in lotus position (结 跏跃坐), the face is damaged. The figure of the Buddha is carved using a bas-relief technique.

The following are the Buddha figures sculpted on the base or cast on the trunk of a money tree:

The Buddha on the ceramic base of a money tree in Pengshan County（彭山 摇钱树 陶质 底座 佛像） (Fig. 2) was discovered in 1942 during excavations of a rocky grave of Eastern Han in Pengshan County, Sichuan Province. The seated Buddha is on a ceramic base of the money tree. He is without a halo above his head, with a high ushnisha, in a cape over his shoulder, his left hand is in Abkhay mudra, his right hand is holding the edge of his clothes. Two figures of people in the vestments of northern foreigners (胡人) are molded to the right and to the left of the Buddha. The person on the left is standing with his hands in front of his chest and his head is thrown back in a praying pose. A relief with a dragon and a tiger, which is holding the yuanbi element (圆 壁 a type of ritual utensil, a disk with a hole in the middle) in its teeth, is carved at the bottom of the Buddha figurine.

The early Buddhist sculptures of the southern part of Shandong province and the northern part of Jiangsu province and related regions include the remains of stone carved Buddhist figures in burials and rock graves.

Graves with stone reliefs of the Han era, Yinan County (沂南 汉代 画像 石墓). In 1954, graves from the late Eastern Han period were discovered in the village of Beizhai, Innan County, Shandong (山东沂南县 北 寨村). In the middle burial chamber at the upper end of the octagonal column, a figure of a child in a standing pose with a halo above his head is carved from the north and south sides. On the south side, a seated Buddha is carved under the child's figure. There is an ushnisha on the head of the Buddha, and wings are on the shoulders; the left hand is located in front of the chest, the right one is in Abhay mudra.

The rock carvings on Kunwan Shan Mountain (孔 望 山摩崖 石刻) (Fig. 3) are located in the Haizhou District of Lianyungang City, Jiangsu Province. In the 80 s of the $20^{\text {th }}$ century, it began to attract the attention of the scientific community. Opinions regarding the dating of its creation vary. Rock sculptures on Kunwan Shan Mountain are concentrated in its southwestern part. About 105 relief figures of people of different sizes are carved on the surface of the mountain, the highest of which is $1.54 \mathrm{~m}$ and 

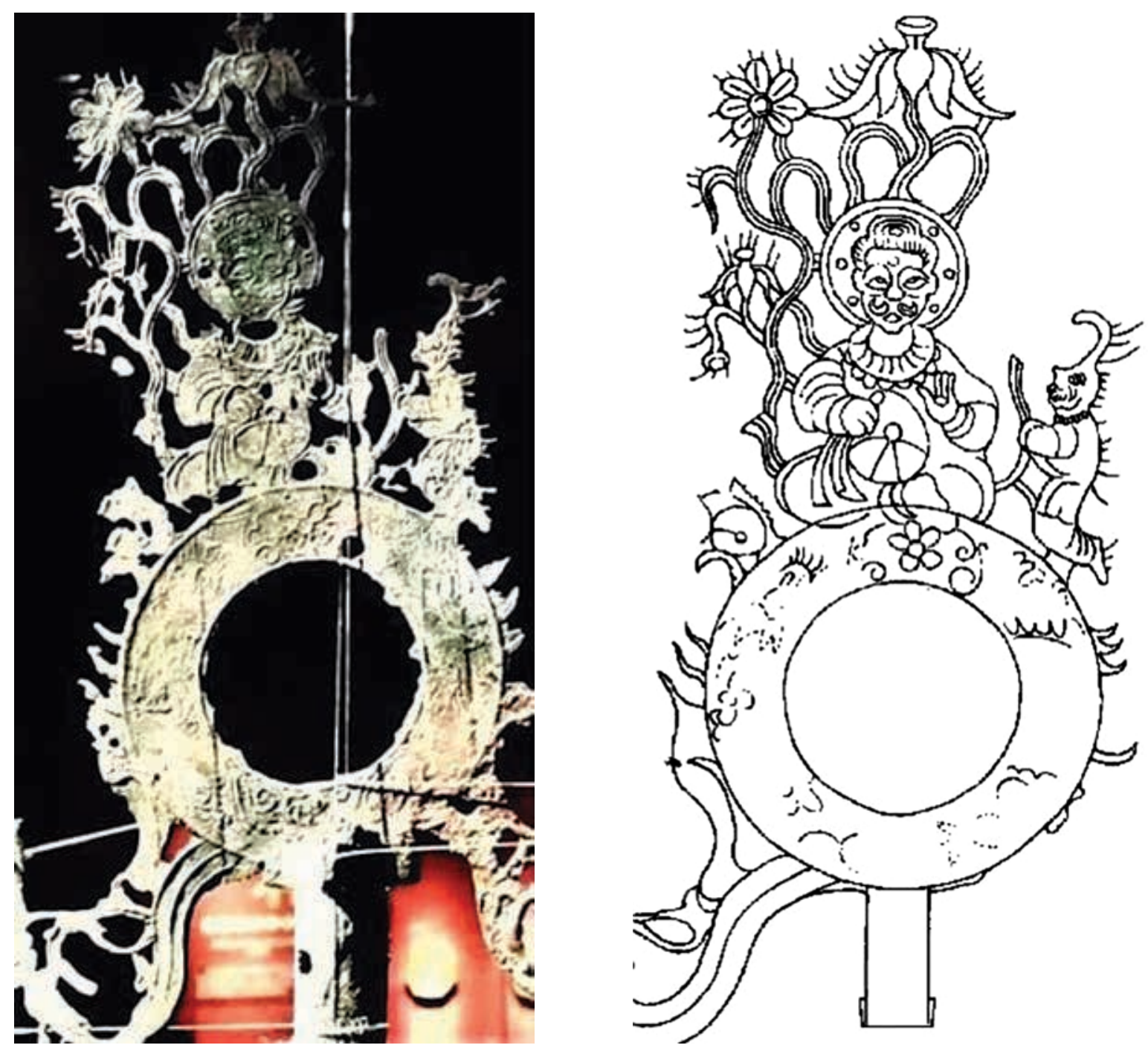

IIl. 4. Buddha figures on a money tree from Chengdu, Shaanxi Province. Bronze. II-III centuries. Height $5 \mathrm{~cm}$, width $2.5 \mathrm{~cm}$. Chengu Museum

the lowest is $10 \mathrm{~cm}$. Sculptures with signs characteristic of the Buddha are among them. A common sign is an ushnisha as well as the left hand holding the edge of the garment and raised in front of the chest, and the right one in Abhay mudra.

In the northwestern region, early Buddhist sculptures include the Buddha figures on a money tree found in Chengdu County, Shaanxi (陕西 城固)， brick reliefs excavated from a burial site dating from the late Eastern Han to the Three Kingdoms in Pingan County, Qinghai (青海平安县).

The Buddha figures on a money tree from Chengdu Province Shaanxi （陕西 城固 摇钱树 佛像）(Fig. 4) were discovered in 1957 in the grave of the Eastern Han era in Chengdu Province Shaanxi. Now they are stored in the cultural center of Chengu County. The Buddha figure is located in the center of the money tree; together with the halo, its height is $6.5 \mathrm{~cm}$, the width is $4.1 \mathrm{~cm}$. The Buddha is in the lotus position, the right hand in Abhai mudra, the left one is holding the edge of the clothes, there is an ushnisha on his head (肉 䯽), an urn (the so-called third eye, a symbol of spiritual vision and essence) is on the forehead, there are mustaches sticking up under his nose. A kashai (袈裟) is thrown over his shoulder, there is a decor with a lotus-like ornament in the neckline of the collar. A man facing him, kneeling and bowing is on the right side of the Buddha figure. There is a high headdress on his head, a mustache under his nose. The figures of the Buddha and the worshiper are located on a particularly large element of the yuanbi (圆 壁). There is a lotus-like ornament at the back of the seated Buddha.

Brick reliefs from the eastern Han burial ground in Ping'an County, Qinghai（青海平安区 东汉 画像 砖砖) (Fig. 5), were discovered in 1982 in a burial dating from the late Eastern Han to the Three Kingdoms in the Ping'an District of Haidong City, Qinghai Province. In total, 6 bricks with reliefs were extracted. The scene on one of them depicts a hip-roofed building (底 殿顶), in which two people are sitting oppo- 


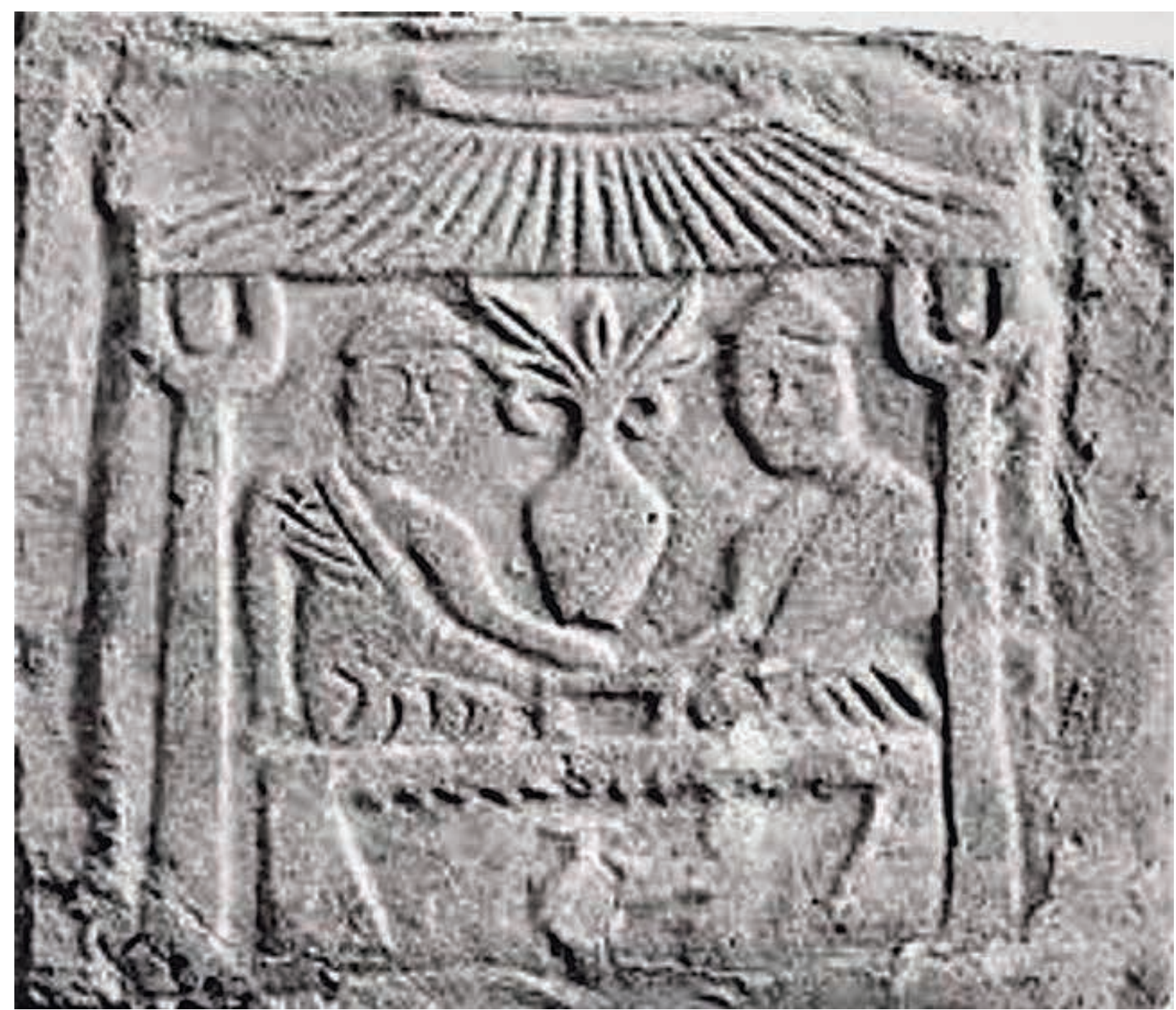

IIl. 5. Brick reliefs from the burial period of the Eastern Han in Ping'an County, Qinghai province. Clay. Height $20 \mathrm{~cm}$, width $16 \mathrm{~cm}$. II century. Qinghai Museum

site each other in a lotus position in monastic hats, in kashais, their left arms are bare and their right arms are perpendicular to their knees. A table with a ritual vase on it is between these two people. Under the table, there is a small figure of a man who is taking a vessel into his hands and kneeling, being a servant.

The early Buddhist sculptures of the Middle and Lower Yangtze River mainly include the Buddha images on bronze mirrors, stucco molding (堆塑) on hunping vessels (魂 瓶) or the Buddha images made in the flat stucco technique (贴 塑) as well as porcelain figurines with urn (白毫 相), ceramic Buddha figurines taken from burial sites.

At the moment, the earliest discovered bronze mirrors in China with decorative Buddha images are mirrors taken from the burial sites of the Western Jin era in the Middle and Lower Yangtze River.

A bronze mirror with eight phoenixes, figures of the Buddha and mythological animals（八 凤佛像
神兽 铜镜) (Fig. 6) was found in 1975 in the city of Ezhou, Hubei province (湖北省 鄂州市)，and is currently stored in the Ezhou museum. Its diameter is $14.2 \mathrm{~cm}$. In the inner part, there is a pattern in the form of 4 petals. The one-legged dragon Kui (咱 兽) is depicted on three of them, and one shows the profile of a man sitting in a pose of contemplation, with a high headdress, with a long mustache, and his hands are folded in the Dhyan mudra. The edge of the inner part is formed by an arcuate ornament of 12 arcs. Inside the arcs, there were ornaments with animals and birds (飞禽走兽). It is established that the mirror dates from the era of Western Jin, the place of manufacture is in the Wuchang district of the Eastern W kingdom (Three Kingdoms).

At present, among the discovered hunping vessels (魂 瓶) with the Buddha figures, as well as among the celadon dishes（青瓷 器血）with the sculpted Buddha figures, there are mainly those that were extracted 


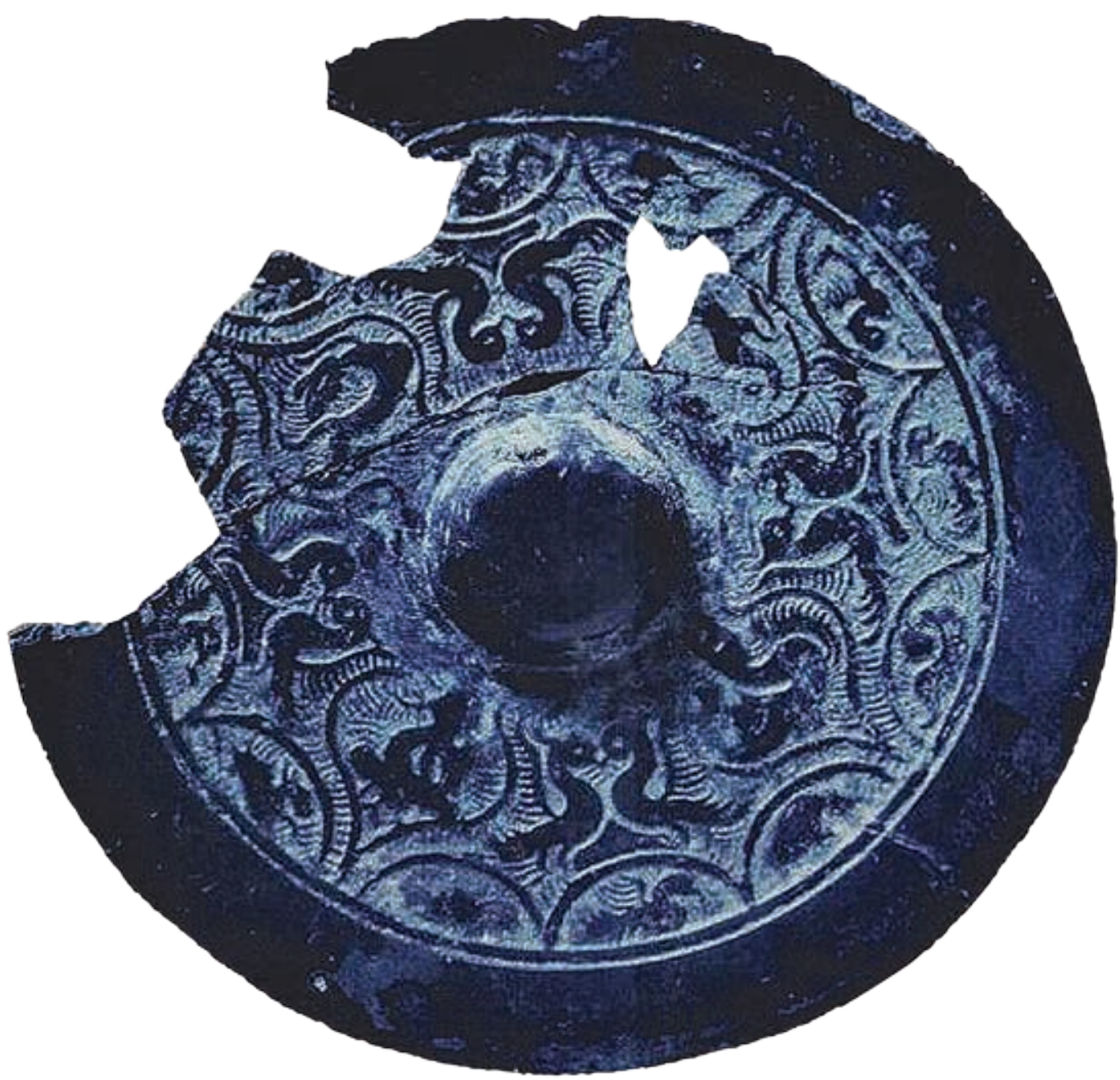

IIl. 6. A bronze mirror with eight phoenixes, figures of a Buddha, and mythological animals. III century. Bronze. Its diameter is $14.2 \mathrm{~cm}$. Ezhou Museum

from burials of the period of the kingdom of East Wu and West Jin in the regions of Jiangsu and Zhejiang.

Red Ceramic hunping with Buddhist decor (红陶 佛饰魂瓶瓶) (Fig. 7) was discovered in 1979 in the tomb of the era of the Eastern Wu kingdom in Wuku Village, Yingyang District, Jiangning District, Nanjing City, Jiangsu Province (江苏南京江宁县殷 巷 巷乡五库村). It is currently stored in the Nanjing City Museum. Based on the structure of the burial and the items buried with the deceased, it can be determined that the burial was made from the Ufeng period of reign to the Tien Shan period of reign（五凤至天册年间，254-275). The height of the vessel is $37.2 \mathrm{~cm}$, the girth of the body is $23 \mathrm{~cm}$.
Birds are made in the upper part of the vessel using the stucco molding technique, and a square pavilion with a hip roof is on top. The bottom on the front side is a multi-tiered tower, birds are sheltered on each cornice. A turret (阙) was on both sides of the tower. Seven Buddha figures were made behind. The Buddhas were in a kashai thrown over their shoulders, they had ushnishas on their heads, halos behind their backs, their hands were folded in the Dhyan mudra, and they were sitting on the base of a lotus with images of two lions.

Porcelain figurines with an urn, a sign of the Buddha, were mainly found in the area of the Middle and Lower Yangtze River in graves belonging to eras from 

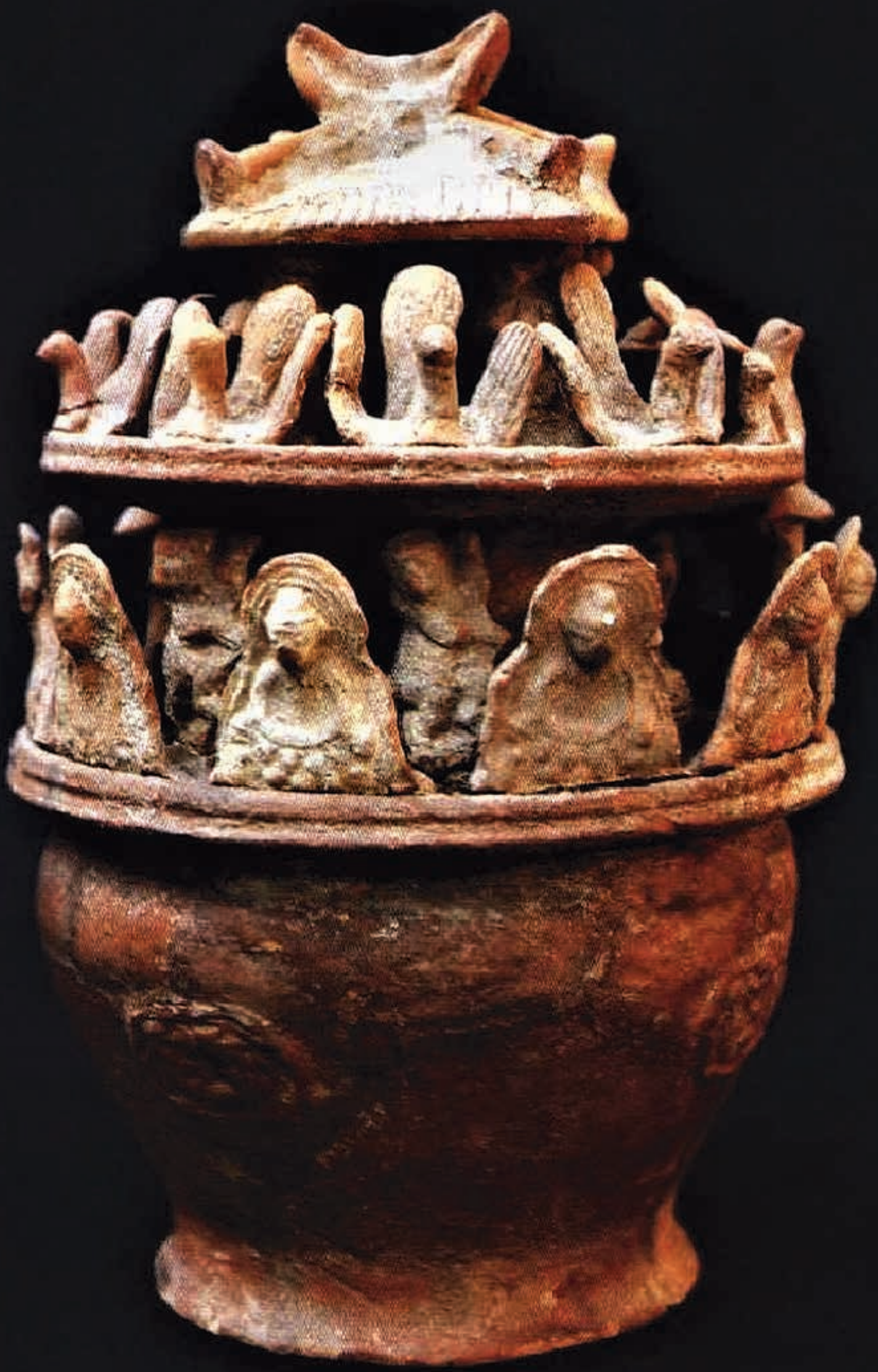
the kingdom of Eastern Wu to Western Jin. Four statuettes, covered with dark green glaze, which were taken from a burial site dated to the fifth year of the reign during the Yun'an period (262) of the East Wu kingdom in the Lianxi-si monastery in the Wuchang district of Wuhan, Hubei province（湖北 武汉 武昌 区 莲溪 寺), a group of celadon statuettes from the grave of Western Jin in Changsha, Hunan (湖南 长沙). All of them have urns, a hallmark of the Buddha image.

After putting in order and combining the above material on the remains of early Buddhist sculptures, the following features of the art of sculpture can be distinguished:

In many ways, the early Buddhist sculptures expressed the early style of Gandhara（健 陀罗 风格). Firstly, sculptures in a seated position, with a right hand folded in the Abhay mudra and a left hand holding clothes, were also common among the early Buddhist sculptures of the Gandhara style. Secondly, a bun of hair as an ushnisha is also a hallmark of hair of the Buddhist Gandhara style sculptures. Thirdly, with regard to the face, a mustache was often depicted on it; among Indian Buddhist sculptures, this could only be found in the Gandhara region, and this was mainly common in early Gandhara style sculptures.

The early Buddhist statues were closely related to the subjects of the celestials and Huang Lao (神仙 黄老). This feature was predetermined by the Buddhist beliefs of that time. The Chinese regarded
Buddhism as a high art of celestials. Buddhist images were closely connected with the images of celestials, wonderful birds, beasts foreshadowing luck, and other traditional images, especially with the image of the goddess Sivanmu（西 王母).

The works of Buddhist sculpture did not occupy the most respected position. During that era, Buddhism had not yet received comprehensive development, it was only the initial spreading. The factual material confirms that there were many Buddhist sculptures that were not worshiped. These sculptures mainly performed a decorative function, symbolizing happiness and prosperity, and were not the main object of worship. The hunping vessels (魂瓶) as funeral utensils (冥器) meant a blessing petition for the deceased.

Summarizing the above, two conclusions can be drawn. The art of early Buddhist sculptures and religion basically developed synchronously; after appearing in China, the art of Buddhist images immediately became Chinese. (汉化).

The style of the early Buddhist sculptures changed, following the profound development of Buddhism in China. Starting from the era of Eastern Jin and the Sixteen Kingdoms（东晋十六国, 317-420), the sculpture experienced a rapid rise, stone caves became widespread, and ceramic figures of the Buddha, along with bronze mirrors and other decorative objects with celestials, fell into disuse and disappeared.

\section{REFERENCES}

1. Liang Xicheng. 1998. The History of Chinese Sculpture. Tianjin: Bayhua Publishing House of Literature and Art. (in Chinese)

2. Jin Weino, Luo Shiping. 1995. The History of Chinese Religious Art. Nanchang: Jiangxi Art Publishing House. (in Chinese)

3. Yang Hongxun. 2008. Collection of Articles of Architectural Archeology. Beijing: Tsinghua University Press (in Chinese)

4. Ren Jiyu. 1985. The History of Chinese Buddhism. Beijing: China Social Sciences Publishing.. vol. 1. (in Chinese)

5. Xiao Ping. 2005. "On the Secularization of the Art of Buddhist Statues in China", Journal of Southwestern National University, no. 12, pp. 364-366. (in Chinese)
6. Hopfener, B. 2019. "Tradition and transmission: Shifting epistemological and (art-)historical grounds of contemporary art's relation to the past", Journal of Contemporary Chinese Art, vol.6, no.2-3, pp. 187-206. DOI: 10.1386/jcca_00003_1 (in English)

7. Rhi, Juhyung. 2008. "Identifying Several Visual Types in Gandhāran Buddha Images", vol. 58, no.1, pp. 43-85. DOI:10.1353/aaa.0.0001 (in English)

8. Quintanilla, S. R. 2017. "Transformations of Identity and the Buddha's Infancy Narratives at Kanaganahalli", Archives of Asian Art, vol. 67, no.1, pp. 111-142. DOI: 10.1215/00666637-3788663 (in English) 


\section{БУДДИЙСКАЯ СКУЛЬПТУРА КИТАЯ РАННЕГО ПЕРИОДА: ИКОНОГРАФИЧЕСКИЕ ОСОБЕННОСТИ}

Аннотация. В данной статье рассматривается период развития искусства буддийской скульптуры от средней и поздней эпохи Восточной Хань до эпохи Западной Цзинь. Буддийские скульптуры этого периода называют китайскими буддийскими скульптурами раннего периода.

В этот период - до того, как появились индивидуальные буддийские скульптуры в качестве официального объекта поклонения, - опирались на изображения будды на резьбе по камню в гробницах, на денежных деревьях, бронзовых зеркалах, сосудах хуньпин и т.д. Они имеют много сходств между собой и поэтому ощутимо отличаются от буддийских скульптур более позднего периода. Исходя из имеющихся на данный момент археологических материалов, основной формой буддийских скульптур этого периода был рельеф; скульптуры в основном выполняли функцию декора, а не были объектом поклонения. В плане назначения и смыслового содержания они были связаны главным образом с погребальным ритуалом, верования-

К ранним буддийским скульптурам в Китае относят те, которые датируются эпохами поздней Восточной Хань (东汉中晚期, 90-220 годы), Троецарствия (三国, 220-280 годы) и Западной Цзинь (西晋, 266-316 годы). В этот период - до того, как появились индивидуальные буддийские скульптуры в качестве официального объекта поклонения, - опирались на изображения будды на резьбе по камню в гробницах（墓葬石刻）, на денежных деревьях (摇钱树) 1, бронзовых

1. Денежное дерево（摇钱树）— погребальная утварь, используемая в регионах Сычуань, Чунцин и пр. в эпохи Хань и Вэй. Этот предмет состоял из основания и ствола дерева с листьями. Основание было керамическим, встречались также бронзовые и каменные основания: в большинстве своём они имели форму горы, сужающейся кверху, также встречались в форме барана, льва, головы зверя и др. На верхней части основания было отверстие диаметром от 1 до 5 см, в которое вставлялся ствол дерева. Ствол и листья отливали из меди. Ствол был сравнительно длинным и со- ми о счастливых предзнаменованиях, о небожителях, ранними даосскими и другими идеями и т.п.

После упорядочения и объединения материала об остатках ранних буддийских скульптур можно выделить следующие особенности искусства скульптуры:

1. Во многом ранние буддийские скульптуры выражали ранний стиль Гандхары. 2. Ранние буддийские изваяния были тесно связаны с тематикой небожителей и Хуан-Лао. 3. Произведения буддийской скульптуры отнюдь не занимали самое уважаемое положение. Эти скульптуры главным образом выполняли декоративную функцию, символизировали счастье и благополучие и не являлись основным объектом поклонения.

Отсюда можно сделать два вывода: развитие искусства ранних буддийских скульптур и религии в основном шло синхронно; после прихода в Китай искусство буддийских образов сразу китаизировалось.

Ключевые слова: буддийская скульптура Китая раннего периода, рельеф, декоративный стиль Гандхары. зеркалах（铜镜） 2, сосудах хуньпин (魂瓶) 3

стоял из частей, количеством от 4 до 6 . В каждой из них было по четыре отверстия, через которые подвешивали один или два листка. На листьях обычно отливали фигурки феникса, богини Сиванму, бессмертных святых, дракона, растений, монет и др. Техника, используемая при литье фигурок будды на денежном дереве, обладает классической простотой эпохи Хань, лаконичностью и стилем резьбы, сочетающим общность и детальность.

2. Бронзовые зеркала (铜镜) - зеркала, отлитые из бронзы. Такие зеркала являлись бытовыми предметами Древнего Китая, а также погребальной утварью, часто встречающейся в захоронениях. На обратной стороне зеркал обычно отливали надписи и изящные узоры

3. Хуньпин (魂瓶), другое название гуцан гуань - погребальная утварь, часто встречающаяся в захоронениях района среднего и нижнего течений реки Янцзы. Форма предмета в эпоху Хань - 3 сосуда, соединённых вместе, либо позже трансформировавшаяся в пять сосудов. К эпохам У и Цзинь форма постепенно установилась. Обычно на сосуде и его корпусе выполняли плоскую либо объёмную лепнину в виде различных духов гор и морей, роскошных зданий, журавлей, которые символизировали вознесение души в царство небожителей. 
и т.д. В плане назначения и смыслового содержания они были связаны главным образом с погребальным ритуалом, верованиями о счастливых предзнаменованиях, о небожителях, ранними даосскими и другими идеями и т.п.

В период от средней и поздней династий Восточной Хань (90-220 годы) до царств Шу-Хань Троецарствия（三国蜀汉221-263 годы) ранние буддийские скульптуры частично были расположены в юго-западном регионе Китая（西南地区）; южной части провинции Шаньдун, северной части провинции Цзянсу и прилегающих регионах

（鲁南苏北地区）; в период от царства Восточного У Троецарствия（三国东吴222-280 годы) до Западной Цзинь (西晋266-316 годы) - в районах среднего и нижнего течений реки Янцзы (长江中下游地区).

К ранним буддийским скульптурам юго-западного региона (西南地区) главным образом относятся остатки скульптур из провинции Сычуань (四川).

Исходя из фактических археологических материалов, среди каменных резных рельефов с изображениями будды на перемычках дверей скальных могил присутствуют Каменный рельеф сидящего будды в скальной могиле № 1 - Лэшань, Maxaо (乐山麻浩一号崖墓石刻浮雕坐佛) (рис. 1), который обнаружили в 1940 году в районе Махао города Лэшань, на перемычке двери задней камеры захоронения. Высота фигуры будды составляет 39,5 см, ширина - 30 см. На голове будды была высокая ушниша (肉䯽) - круглый ореол, - на теле - кашая через плечо, с U-образным воротником. На правой руке пальцы сложены в мудру Абхая (施无畏印), левая сжимает пояс. Будда сидит в позе лотоса (结跏跃坐)， лицо повреждено. Фигура будды вырезана в технике барельефа.

Среди фигурок Будды, вылепленных на основании или отлитых на стволе денежного дерева, присутствуют:

Будда на керамическом основании денежного дерева в уезде Пэншань（彭山摇钱树陶质底座佛像） (рис. 2), который был обнаружен в 1942 году при раскопках скальной могилы Восточной Хань в уезде Пэншань провинции Сычуань. На керамическом основании денежного дерева изображён сидящий будда. Он без ореола над головой, с высокой ушнишей, в накидке через плечо, левая рука в мудре Абхая, правая сжимает край одежды. Справа и слева от будды вылеплено по фигурке людей в облачении северных иноземцев（胡人）. Человек слева стоит с руками перед грудью и запрокинутой кверху головой, в молящейся позе. Снизу фигурки будды вырезан рельеф с драконом и тигром, которые сжимают в зубах элемент юаньби (圆壁, вид ритуальной утвари: диск с отверстием посередине).

К ранним буддийским скульптурам южной части провинции Шаньдун и северной части провинции Цзянсу и связанных с ними регионов относят остатки каменных резных буддийских фигур в захоронениях и скальных могилах.

Могилы с каменными рельефами эпохи Хань уезда Инань（沂南汉代画像石墓）. В 1954 году в деревне Бэйчжай уезда Иннань провинции Шаньдун (山东沂南县北寨村) были обнаружены могилы периода поздней Восточной Хань. В средней погребальной камере на верхнем конце восьмиугольной колонны с северной и южной сторон вырезана фигура ребёнка в стоящей позе и с ореолом над головой. На южной стороне под фигурой ребёнка вырезан сидящий будда. На голове будды есть ушниша, на плечах — крылья, левая рука расположена перед грудью, а правая - в мудре Абхая.

Наскальная резьба на горе Кунван-шань (孔望山摩崖石刻) (рис. 3) расположена в районе Хайжоу города Ляньюньган провинции Цзянсу. В 80-х годах XX века она начала привлекать внимание научной общественности. Мнения относительно датирования данного творения различаются. Наскальные скульптуры на горе Кунван-шань сосредоточены в её юго-западной части. На поверхности горы вырезано около 105 рельефных фигур людей разного размера, самая высокая из которых составляет 1,54 м, а самая низкая - 10 см. Среди них есть скульптуры с признаками, характерными для будды. Общим признаком является ушниша; кроме того, левая рука держит край одежды и поднята перед грудью, а правая - в мудре Абхая.

К ранним буддийским скульптурам в северозападном регионе относят фигурки будды на денежном дереве, обнаруженные в уезде Чэнгу провинции Шэньси （陕西城固）, кирпичные рельефы, извлечённые из захоронения, датируемого периодом от поздней восточной Хань до Троецарствия в уезде Пинъань провинции Цинхай (青海平安县)

Фигурки будды на денежном дереве из уезда Чэнгу провинции Шэньси （陕西城固摇钱树佛像） (рис. 4) были обнаружены 
в 1957 году в могиле эпохи Восточной Хань в уезде Чэнгу провинции Шэньси. Сейчас они хранятся в Доме культуры уезда Чэнгу. Фигурка будды расположена в центре денежного дерева, вместе с ореолом её высота составляет 6,5 cм, ширина - 4,1 cм. Будда сидит в позе лотоса, правая рука в мудре Абхая, левая сжимает край одежды, на голове есть ушниша (肉䯽), на лбу - урна (т. н. третий глаз, символ духовного видения и сущности), под носом 一 усы, торчащие вверх. Кашая（袈裟） накинута через плечо, в области выреза воротника есть декор с орнаментом, похожим на лотос. С правой стороны от фигурки будды изображён человек, обращённый к нему, стоящий на коленях и совершающий поклон. На голове высокий головной убор, под носом - усы. Фигурки будды и совершающего поклон человека расположены на особенно крупном элементе юаньби（圆壁）. Сзади сидящего будды есть орнамент, похожий на лотос.

Кирпичные рельефы из захоронения периода восточной Хань в уезде Пинъань провинции Цинхай（青海平安区东汉画像砖） (рис. 5) были обнаружены в 1982 году в захоронении, датируемом периодом от поздней Восточной Хань до Троецарствия в районе Пинъань города Хайдун провинции Цинхай. Всего было извлечено 6 кирпичей с рельефами. Сюжетом одного из них является здание с вальмовой крышей（㢁殿顶）, в котором два человека сидят друг напротив друга в позе лотоса, в монашеских шапках, в кашаях, левая руки у них обнажены, а правые расположены перпендикулярно коленям. Между этими двумя людьми находится стол, а на нём - ритуальная ваза. Под столом - маленькая фигурка человека, который принимает в руки сосуд и преклоняет колени, являясь прислужником.

К ранним буддийским скульптурам районов среднего и нижнего течений реки Янцзы главным образом принадлежат изображения будды на бронзовых зеркалах, объёмная лепнина (堆塑) на сосудах хуньпин (魂瓶) либо изображения будды в технике плоской лепнины（贴塑）, а также фарфоровые статуэтки с урной (白毫相), керамические фигурки будды, извлечённые из захоронений.

На данный момент самыми ранними из обнаруженных в Китае бронзовых зеркал с декоративными изображениями будды являются зеркала, извлечённые из захоронений эпохи Западной Цзинь в районе среднего и нижнего течений реки Янцзы.
Бронзовое зеркало с восемью фениксами, фигурками будды и мифологическими животными （八凤佛像神兽铜镜）(рис. 6) было найдено в 1975 году в городе Эчжоу провинции Хубэй （湖北省鄂州市） и на данный момент хранится в музее г. Эчжоу. Диаметр его составляет 14,2 cм. Во внутренней части расположен узор в форме четырёх лепестков. На трёх из них изображён одноногий дракон Куй (敨兽), а на одном - профиль человека, сидящего в позе созерцания, с высоким головным убором и длинными усами, руки сложены в мудре Дхьяна. Край внутренней части образован дугообразным орнаментом из 12 дуг. Внутри дуг были орнаменты со зверями и птицами (飞禽走兽). Установлено, что зеркало датируется эпохой Западной Цзинь, место изготовления - в округе Учан царства Восточное У (Троецарствие).

На данный момент среди обнаруженных сосудов хуньпин (魂瓶) с фигурками будды, а также среди селадоновой посуды (青瓷器血) с вылепленными фигурками будды главным образом имеются те, которые были извлечены из захоронений периода царства Восточного У и Западной Цзинь в регионах провинций Цзянсу и Чжэцзян.

Хуньпин из красной керамики с буддийским декором (红陶佛饰魂瓶) (рис. 7) был обнаружен в 1979 году в могиле эпохи царства Восточного У в деревне Уку волости Инсян района Цзяннин города Нанкин провинции Цзянcy（江苏南京江宁县殷巷乡五库村）. На данный момент хранится в городском музее Нанкина. Исходя из структуры захоронения и предметов, захороненных вместе с умершим, можно определить, что захоронение было сделано в период от правления под девизом Уфэн до правления пол девизом Тяньшань（五凤至天册年间, 254-275 годы). Высота сосуда составляет 37,2 см, обхват тулова - 23 см. В верхней части сосуда в технике объёмной лепнины выполнены птицы, а сверху квадратный павильон с вальмовой крышей. Снизу на лицевой стороне выполнена многоярусная башня, на каждом карнизе приютились птицы. По обеим сторонам башни было по башенке цюэ (阙). Сзади были выполнены 7 фигур будды. Будды были в кашае, наброшенной через плечо, на голове у них была ушниша, ореол за спиной, руки сложены в мудре Дхьяна, и сидели они на основании виде лотоса с изображениями двух львов.

Фарфоровые статуэтки с урной - признаком будды - главным образом обнаруживали 
в районе среднего и нижнего течений реки Янцзы в могилах, принадлежащих эпохам от царства Восточного У до Западной Цзинь. Четыре статуэтки, покрытые тёмно-зелёной глазурью, которые были извлечены из захоронения, датированного пятым годом правления под девизом Юнъань (262 год) царства Восточное У в монастыре Ляньси-сы в районе Учан города Ухань провинции Хубэй （湖北武汉武昌区莲溪寺）, группа селадоновых статуэток из могилы Западной Цзинь в городе Чанша провинции Хунань（湖南长沙） - все они имеют урны (отличительную черту образа будды).

После упорядочения и объединения вышеизложенного материала об остатках ранних буддийских скульптур можно выделить следующие особенности искусства скульптуры:

Во многом ранние буддийские скульптуры выражали ранний стиль Гандхары（健陀罗风格）. Во-первых, скульптуры в сидящей позе, с правой рукой, сложенной в мудре Абхая, а левой сжимающей одежду, также были распространены среди ранних буддийских скульптур стиля Гандхары. Во-вторых, пучок волос в качестве ушниши также является отличительной чертой волос у буддийских скульптур стиля Гандхары. В-третьих, что касается лица, то на нём часто изображали усы; среди индийских буддийских скульптур это можно было встретить только в регионе Гандхары, и в основном это было распространено у ранних скульптур стиля Гандхары.

Ранние буддийские изваяния были тесно связаны с тематикой небожителей и Хуан-Лао (神仙黄老). Эта особенность была предопре- делена тогдашними буддийскими верованиями. Китайцы смотрели на буддизм как на высокое искусство небожителей. Буддийские образы были тесно связаны с образами небожителей, чудесных птиц и зверей, предвещающих удачу, а также с другими традиционными образами, особенно богини Сиванму （西王母）.

Произведения буддийской скульптуры отнюдь не занимали самое уважаемое положение. В эту эпоху буддизм ещё не получил всестороннего развития, это было лишь начальное его распространение. Фактический материал подтверждает, что было много буддийских скульптур, которым не поклонялись. Эти скульптуры главным образом выполняли декоративную функцию, символизировали счастье и благополучие и не являлись основным объектом поклонения. Сосуды хуньпин (魂瓶) как погребальная утварь（冥器）означали прошение о благословении для усопшего.

Обобщая вышеизложенное, можно сделать два вывода: развитие искусства ранних буддийских скульптур и религии в основном шло синхронно; после прихода в Китай искусство буддийских образов сразу китаизировалось (汉化).

Стиль ранних буддийских скульптур менялся, следуя за глубоким развитием буддизма в Китае. Начиная с эпохи Восточной Цзинь и 16 варварских государств（东晋十六国, 317-420 гг.) скульптура испытала бурный подъём, каменные пещеры получили распространение, а керамические фигурки будды вместе с бронзовыми зеркалами и другими декоративными предметами с небожителями пришли в упадок и исчезли.

\section{БИБЛИОГРАФИЯ}

1. Лян Сычэн. История китайской скульптуры. Тяньцзинь: Издательство литературы и искусства Байхуа, 1998.

2. Цзинь Вэйно, Ло Шипин. История китайского религиозного искусства. Наньчан: Цзянсиское художественное издательство, 1995.

3. Ян Хунсюнь. Сборник статей архитектурной археологии. Пекин: Издательство университета Цинхуа, 2008.

4. Жэнь Цзиюй. История китайского буддизма. Пекин: Издательство «Общественные науки», 1985. Том 1.

5. Сяо Пин. Об обмирщении искусства буддийских статуй в Китае // Журнал Юго-западного национального университета. 2005. № 12. С. 364-366.
6. Hopfener, B. 2019. "Tradition and transmission: Shifting epistemological and (art-)historical grounds of contemporary art's relation to the past», Journal of Contemporary Chinese Art, vol.6, no.2-3, pp. 187-206. DOI: 10.1386/jcca_00003_1

7. Rhi, Juhyung. 2008. «Identifying Several Visual Types in Gandhāran Buddha Images», Archives of Asian Art, vol. 58, no.1, pp. 43-85. DOI:10.1353/aaa.0.0001

8. Quintanilla, S. R. 2017. «Transformations of Identity and the Buddha's Infancy Narratives at Kanaganahalli», Archives of Asian Art, vol. 67, no.1, pp. 111-142. DOI: 10.1215/00666637-3788663 